\title{
The One-Dimensionality of Econometric Data: The Frankfurt School and the Critique of Quantification
}

\author{
Scott Timcke \\ Independent Scholar, stimcke@gmail.com
}

\begin{abstract}
Econometric data are used to produce authoritative facts about the world. Yet, as numbers enjoy a central place in modern reasoning (particularly in government as their presumed objectivity and neutrality assist impartial decision-making), it is important that they receive scrutiny. Using methodological techniques from Western Marxism, with special reference to the work of Lukács, Horkheimer and Adorno, and Marcuse to inform a critique of Acemoglu and Robinson, I argue that the historical emergence of econometrics as a mode of mediated knowledge is a reified practice within the broader technical administration of social life, a practice that is not a transparent representation of social phenomena. This is because when econometrics transforms the thing being measured into a statistical indicator it eclipses political disputes with technical disputes, sidestepping good faith democratic deliberation about what goods are worth pursuing. Effectively, one-dimensional thought cannot perceive the origins of items put into circulation and so ideology is produced - what seems value-free is value-laden.
\end{abstract}

Keywords: econometrics, data, reification, ideology, numbers

Acknowledgement: A previous version of this article was presented at the 2018 International Critical Theory Conference of Rome, Loyola University Chicago. Special thanks go to Rick Gruneau, Beverley Best, Graham Mackenzie, and the two anonymous reviewers.

\section{Introduction}

Daron Acemoglu and James Robinson are among the leading figures in contemporary American political economics. ${ }^{1}$ Their book Why Nations Fail was shortlisted for the 2012 Financial Times and Goldman Sachs Business Book of the Year and included in the Washington Post's 'ten best books' for the same year. Their previous book, Economic Origins of Dictatorship and Democracy, was similarly well received, being awarded the 2007 American Political Science Association's Woodrow Wilson Award. Allan Drazen called their book "truly path-breaking" $(2007,163)$ and William Easterly described it as "one of the most important contributions to the literature on the economies of democracy in a very long time" $(2007,173)$. With this acclaim, it is fair to say that Acemoglu and Robinson represent a predominant and prizewinning branch of political economic analysis conducted in the United States, a kind of political economy especially concerned with macro-economic growth.

1 To give some indication of their clout, Acemoglu and Robinson's work has been cited 150,221 and 77,139 times respectively, although there is some overlap because they publish together. See their Google Scholar profiles at https://scholar.google.com/citations? user=190r8EMAAAAJ\&hl=en and https://scholar.google.com/citations?user=rNHDppMAAAAJ\&hl=en. Based upon the RePEc bibliometrics, Acemoglu is the most cited economist of the past decade. Robinson is in 101st place, which is also impressive given that he identifies his field as and publishes in political science. See https://ideas.repec.org/top/top.person.all10.html. 
One of their core beliefs is that the United States has a high degree of democratisation because of its inclusive economic institutions (Acemoglu and Robinson 2012a, 74). In my view this assessment is hard to sustain when considering that the American $1 \%$ owns $36 \%$ of all private wealth, $40 \%$ of all financial wealth, $50 \%$ of stocks, and over $60 \%$ of business equity (Wolff 2014; also see Wolff 2017; Saez and Zucman 2014). Indeed, together the three wealthiest American billionaires - Jeff Bezos, Bill Gates and Warren Buffett - have more wealth than the bottom 50\% of the American population, nearly 165 million people (Collins and Hoxie 2017, 2). It is not that Acemoglu and Robinson have simply made a forgivable error about the nature of economic inclusivity, but rather that their methodology is liable to generate these kinds of claims in the first place. This is because they do not fully recognise that "economics is how modern politics is conducted" (Timcke 2017, 2). This vignette seeks to convey some of the characteristics of contemporary American political economy, a field where econometric data has been employed to produce authoritative facts about the world, but through methodological nationalism papers over the extraction and transfer of surpluses from exploited regions.

As numbers enjoy a central place in modern reasoning, particularly in government as presumed objective neutrality assists impartial decisions, it is important that this 'politics by quantities' receives scrutiny. Using methodological techniques from Western Marxism - with special attention to Lukács, Adorno and Horkheimer, and Marcuse - I argue that the emergence of econometrics as a mode of mediated knowledge is a reified practice within the broader technical administration of social life, a practice that is not a transparent representation of social phenomena. This is because when econometrics transforms the thing being measured into a statistical indicator it eclipses political disputes with technical disputes, sidestepping good faith democratic deliberation about what goods are worth pursuing. Moreover, there are parallels between the use of econometric models and Marx's analysis of the commodity form: one-dimensional thought cannot perceive the origins of items put into circulation. What seems valuefree is value-laden. And so, Marx's insight that bourgeois thought concerns itself with objects that arise either from the process of studying phenomena in isolation, or from the division of labour and specialisation in the different disciplines, remains valid. In effect, a 'politics by quantities' dissipates the social question.

The goal in this article is to demonstrate how econometrics as a mode of knowledge production understands, organises and controls social life the world over. There are several steps involved in this argument. In Section 2 I review how Acemoglu and Robinson, as emblematic of orthodox American political economy, conceptualise their symbolic reasoning, and how this quantification comes to mediate social phenomena, thereby determining them as objects. I build upon these observations in Section 3 through undertaking a selective historical analysis on the role of statistical inquiry during European state formation as it relates to accomplishing economic growth. The remaining section employs Western Marxism's critique of quantification to highlight what is at stake in the symbolic reordering of social life as well as what kinds of mystifications are courted by econometrics. I conclude by offering thoughts on the importance of leveraging this later critique to analyse the econometric practices in contemporary data brokerage.

\section{Acemoglu and Robinson's Econometrics}

Why Nations Fail uses narrative case studies to distinguish between 'inclusive institutions' and 'extractive institutions'; it is nevertheless written in the tradition of institutional analysis and guided by rational choice theory towards questions about the relative 
wealth of nations. Even so, it can best be thought of as the simplified companion piece to the econometrically dense Economic Origins of Dictatorship and Democracy. The institutional analysis that Acemoglu and Robinson conduct concludes that concentrating power within an elite almost always inhibits a country's economic success, because the elite enrich themselves at the expense of economic growth. By contrast, inclusive institutions tend to be more successful in the long run because they make pro-growth choices which in turn increase prosperity. This is how Acemoglu and Robinson define these key concepts:

Inclusive economics institutions, such as those in South Korea or in the United States, are those that allow and encourage participation by the great mass of people in economic activities that make the best use of their talents and skills, and that enable individuals to make the choices they wish (2012a, 74).

They add that inclusive economics institutions have a robust private property regime backed by rule of law and a state bureaucracy willing and capable to enforce contracts. This system permits capital and labour mobility (Acemoglu and Robinson 2012a, 74). By contrast,

Extractive political institutions concentrate power in the hands of a narrow elite and place few constraints on the exercise of this power. Economic institutions are then often structured by this elite to extract resources from the rest of society. Extractive economic institutions thus naturally accompany extractive political institutions (Acemoglu and Robinson 2012a, 81).

Keeping these concepts and definitions in mind, in the Economic Origins of Dictatorship and Democracy, Acemoglu and Robinson propose that democratisation and authoritarianism depend on three key values:

- The cost of revolution, represented by the symbol $\mu$;

- The cost of repression, represented by $\kappa$;

- The inequality of society, represented by the symbol $\theta$.

Additionally, other relationships can be expressed as such:

- Indifference between revolution and non-democracy with commitment: $\mu^{*}$.

- Indifference between repression and non-democracy with commitment: $k^{*}$.

- Indifference between repression and democracy: $k$ '.

According to their Proposition 6.3, if $\theta \leq \mu$, then the status quo prevails and "elites can stay in power without repressing, redistributing, or democratizing" (Acemoglu and Robinson 2006, 199). In plainer terms, if the social costs of inequality are less than or roughly the same as the social costs of a revolution, then elites can retain power without the need for - or sufficient pressure to - implement egalitarian reforms. In other words, for example, elites would not want to face the prospect of higher taxes or other policies they do not want now or in the future. However, if the social costs of inequality are higher than the social costs of a revolution, then a new set of pathways emerges. Acemoglu and Robinson delineate and express these options as: 
1. If $\mu \geq \mu^{*}$ and $K \geq K^{*}$, repression is relatively costly and so elites redistribute income to avoid revolution.

2. Or if $\mu<\mu^{*}$ and $K^{\prime}<K^{*}$ or $K^{\prime} \geq K^{*}$ and the poor prefer strictly revolution to democracy, or if $\mu \geq \mu^{*}$ and $K<K^{*}$, then the elites use repression to maintain the status quo.

3. Or if $\mu<\mu^{*}$, the poor prefer weak democracy to revolution and $K \geq K^{*}$, then concessions are insufficient to avoid a revolution and repression is relatively costly, then elites opt to democratize. (Acemoglu and Robinson 2006, 199 [paraphrased for slight simplification]).

At this point I want to pause and restate the above basic relationship in plainer terms in order to make the reasoning more apparent. To begin, Acemoglu and Robinson argue that when the social costs of inequality are higher than the social costs of a revolution, elites are faced with three basic strategies. First, given high levels of inequality, if the pressing costs of repression to enforce this inequality are higher than the costs of redistribution, then elites can stave off revolts by initiating democratisation efforts. This can be in the form of redistributing incomes or offering concessions more favourable to the poor majority. If these concessions are insufficient to stave off revolution, a second strategy is that elites continue to repress the poor, for no concessions will dissuade the poor from revolting. The third strategy is for elites to minimise inequalities to an intermediate level to reduce the prospect of a revolution and then offer credible commitment to reallocating power in the future (see Acemoglu and Robinson 2006, 26). More recently, Acemoglu and Robinson have called this third strategy "the narrow corridor" (2019).

These statements, Acemoglu and Robinson believe, "[feature] all the essential elements of our approach to democratization" $(2006,187 ; 181)$. Based upon these econometric statements and a wide array of inputs from multiple datasets, Acemoglu and Robinson's policy prescriptions are construed as merely the logical extension of technical deductions. And so, when substituting the definitions and concepts into these econometric expressions, one arrives at their conclusion that "democracy emerges as an equilibrium outcome only in societies with intermediate levels of inequality" (2006, 199). The inclusion that comes from democratisation, in the long run, returns higher rates of growth. Therefore, it is in the elite's best interest, if they prioritise wealth accumulation, to pursue this option. For the poor, on the other hand, revolutions are difficult collective actions and coordination problems to solve, as well as risking the destruction of productive infrastructure and/or existing wealth. Accordingly, it is in their best interest to accept the prospects of reduced inequality and the reorganisation of power at a later date, while also benefiting from economic growth arising from inclusion.

Acemoglu and Robinson's work has two important conclusions. First, when an elite or narrow ruling class has near-unanimous control, they establish extractive institutions that benefit themselves at the expense of other members of society. However, if control is diffused, or there are checks and balances, higher growth will follow. Second, as and when shocks occur, the kind of institution matters a great deal.. As Acemoglu and Robinson write, "different political institutions lead to different outcomes" $(2006,89)$. Putting stock into the spectrum of extraction and inclusion, it follows that collective bargaining power matters and is valuable on its own terms, as well as increasing national economic performance.

Yet, despite these insights, something is amiss. I think we can begin to see the problem when undertaking a methodological comparison. Consistent between both Economic Origins of Dictatorship and Democracy and Why Nations Fail is the principle 
inversion of the Marxist account of institutions. While Acemoglu and Robinson follow some materialist protocols, like the identification of class struggle over distribution (2006, 20-21), they have two principal objections to Marxian analysis. The first is that they disagree with Marx's materialist explanation about the mode of production producing the superstructure - "it wasn't technology driving the political organization of society, but the political organization and institutions of society determining what technology could be used" (2012b). Second, they regard Communism as "the new absolutism of the twentieth century", calling these regimes "brutal, repressive, and bloody," predicated upon "extractive institutions" (2012a, 431). They firmly hold the belief that Marxist economic theory is in favour of looting the state, enriching the new elite, and so on; that it is extraction under the guise of inclusion.

These criticisms reveal the limits of their methods on their own terms, for they fail to appreciate that it was not the ideological content of these communist institutions that was the problem, but that they were authoritarian. These two characteristics are not identical. Moreover, the USSR itself was an empire; imperial projects are predicated upon extractive logics. A better approach to the study of states and markets, including communist ones, would be to look at the historically unfolding networks of combined and uneven development that do not privilege the nation-state as the boundary of analysis, a task undertaken superbly by Walter Rodney (1981) in How Europe Underdeveloped Africa, or Perry Anderson (1974) in Lineages of the Absolutist State, for instance. In this way, one can see that polities are not isolated entities, unmoored abstractions, but rather are historically formed through and by material forces that permeate and pass through their formal boundaries. In short, the objects that Acemoglu and Robinson study are decontextualised to bracket out any contingency, while also seeking to standardise the subjects of development. I argue that this is because they are wedded to the notion of society-as-an-object, a dynamic that emerges because of their strict adherence to formal quantitative reasoning.

Given that social conditions shape what constitutes trustworthy or sufficient data collection, as well as what constitutes a sound analysis of that data, a critique of econometrics raises epistemological issues about economic practices, in particular on how technological sophistication backed by institutionally based expertise like that enjoyed by Acemoglu and Robinson produces intelligible explications. In the remaining half of this article I outline some ramifications of this kind of mediatisation. I shall first review selected contemporary historians, anthropologists, and sociologists who critique econometric reasoning, as well as the general consensus they reach. But while I think these scholars offer considerable insights, I think their critiques are not radical enough. Accordingly, I then turn to Western Marxism's critique of quantification and leverage to show how Acemoglu and Robinson's work is a deep depoliticisation of social questions.

\section{The Politics of Quantities}

Like most modern sciences, statistics developed concurrently with European state formation, meaning that the history of this disciplinary practice is inflected by the era, notions of progress, conceptions of suitable kinds of things to measure and so on. Beginning in the 17th century the development of central government began to rely upon demographic calculations to govern increasing complex societies. As William Davis writes, "Casting an eye over national populations, states became focused upon a range of quantities [...including] births, deaths, baptisms, marriages, harvests, imports, exports, rice fluctuations." Davies sums up the reconfiguration thus: as parish registries became nationally aggregated, "Statistics would do for populations what cartography 
did for territory" $(2017,1)$. Like cartography, statistical governance was tested in African colonies (Tilley 2011; Breckenridge 2014). This broader colonial gaze, James Scott notes, was put in place by a diligent "civil society" to facilitate the "administrative ordering of nature and society" and institute "the capacity for large-scale engineering", both deemed desirable elements of a "high-modernist view" $(1998,5)$. By the early 20th century, the familiar categories of analysis had been established, and had been put to service by European states as well as by the bourgeoisie in the market.

To poach from John Thompson's analysis of the development of media, this rise of statistical reasoning was "a reworking of the symbolic character of social life", which results in "a reorganization of the ways in which information and symbolic content are produced and exchanged in the social world and a restructuring of the ways in which individuals relate to one another and to themselves" (Thompson 1995, 11). In summary, by the mid-20th century the entire basic repertoire of economic statistics was under consolidation, the by-product of which was to produce a new kind of object for government; new ways of manipulation and effects to be registered, all themselves products of modernity.

Channelling the precept that "statistical facts are produced by particular actors, in particular contexts, with particular interests" (2001, 3), Adam Tooze provides an excellent analysis of the post-war transformations of statistical reasoning in economics. First, he identifies a great "global standardization of the modern repertoire of macroeconomic statistics" that included key variables like "national income, physical production, employment, balance of payments, and volume of money in circulation, and the aggregate price level" (2001, 4; 9-10). Consolidated in a "new empirical image of the economy" this interest in statistical techniques related to "the production of factual economic knowledge" (Tooze 2001, 4; 3). Second, this standardisation rapidly diffused: right after the Second World War, nearly 40 states provided assessments of national income, while a decade later 80 did. "The qualitative change in data was dramatic", he writes $(2001,8)$, as it effectively rendered social questions (questions of unearned rents and divides between labour and capital) irrelevant. Instead the economic interpretation on national income emphasised productivity and the business cycle. The bifurcation of the economy from social relations can be set in contra-distinction to Marx's interest in contesting share. The point is that numerical representations aided the conceptualisation of the economy as growth of national income, a feature that still haunts orthodox economic reasoning, theory, and training.

Much of these elements are reflected in John Maynard Keynes' The General Theory of Employment, Interest and Money. This text can be considered as emblematic of modern macroeconomics, one that greatly enhanced a strand of macroeconomic thinking that developed from the 1870s onwards. As Geoff Mann argues, the influence of Keynes can be attributed less to his originality of research on, say, effective demand or liquidity preference, and more to a receptive audience, ideologically primed both for this message about an administratively engineered recovery of capitalist accumulation and for the scientific expertise in which it was delivered (see Mann 2017). Herein we see all the hallmarks of the high modernism Scott identified. From this point one begins to see, as Tooze writes, "the development of mathematical techniques for analyzing statistical data and testing theory" $(2001,12)$.

By the 1990s, the expansion of econometrics and quantitative modelling was one of the most significant trends in economics and related disciplines, adopted in turn by think-tanks and governments (see Lawrence 2010). Moving from relatively basic assessments such as tallying votes or creating districts for representation, to more com- 
plex assessments like the monitoring and evaluation of public policy, to assessing equitable public spending in state budgets, econometrics is entangled with calculability and control, bureaucratic operations which draw upon evidence for evidence-based public policy, but which really serve the reproduction of hegemonic structures of power and inequality.

Aside from these political issues, epistemologically more pernicious errors occur when inducing correlations using indicators as proxies for other variables, like GDP for development, or Gini coefficients to stand in for elites' instincts for self-preservation or reform. As an example of how method creates explication, consider GDP as an index of economic development. Nominally it is intended to track the economic growth in a state. Nevertheless, Thomas Piketty notes that this indicator "is a reflection of an era when the accumulation of industrial goods was thought to be an end in itself, and to increase in production seen as a solution to everything". The problem of this indicator is that it does not take account of the "depreciation of capital that made production possible", nor the "flow of profits between countries" $(2017,53 ; 54)$. These two oversights mean that per capita incomes based on the GDP can be inflated, such that there is a systematic underestimation of economic hardships. This is but one illustration of the shortcomings of quantified indices. But the more fundamental objection is that using an indicator like GDP reveals prior assumptions and post-hoc rationalisation which simplify a complex array of value judgements, social processes, and political contests. What remains is the common sense of the researcher: or, to put it otherwise, their ideology and the reductions it courts.

At the level of research practice, Morten Jerven writes: "If you ask an economist about the evidence supporting their conclusions, they will direct you to the inferential statistical results and tell you about coefficients of determination, statistical significance and robustness tests". Conversely, "if you ask a historian about evidence, he or she will respond by telling you about the quality of the primary observations" $(2015,16)$. Jerven argues that econometricians commonly lack historical awareness; that they could do with a dose of economic history. But his more important point is that, due to the compromise of the data collection process, datasets bear no resemblance to actually existing social life (Jerven 2013), and so the subsequent econometric analysis, no matter how technically well executed, is not the mirror of economic activity. What appears precise is anything but. It is for these reasons that Jerven argues for a "political ethnography of indicators" that traces "the line of causality from 'data' to 'decisions"” (2016), and which can subject the numbers to closer critical scrutiny to understand the conditions of their production and dissemination.

The anthropologist Sally Engle Merry has perhaps one of the best recent examples of this political ethnography of indicators. For her, quantification of social life is a "mode of governance" stemming from "the desire for accountability" (2016, 3). Quantification is a way to gather and represent empirical knowledge, showing objectively how the world 'really is', thus legitimating their use for political decision-making. All these elements contribute to what she terms the "seductions of quantification", that is, the belief that "technocratic knowledge seems more reliable than political perspectives in generating solutions to problems, since it appears pragmatic and instrumental rather than ideological" (2016, 4). But this not the case. As Bruno Latour and Steve Woolgar (1986) demonstrate in Laboratory Life, numbers are created through a series of decisions with the aid of mathematical models, their simplicity deflecting their constructed character. Likewise, Alain Desrosières notes, quantified objects become "repeated in other assemblages and circulated as such, cut off from their origins - which is after all the fate of numerous products" $(1998,3)$ : their presumed objectivity and universality implies 
that they have a degree of transferability across a range of contexts. In effect, numbers construct and mediate the objects they represent. And, as with all mediations, there is the possibility of deception and misperception. What I mean is that numbers create and make visible the objects they measure. It is in this transformation that numbers take on a life on their own; however, their apparent impartial use in administrative processes has far-reaching consequences.

Orthodox political economists are aware of and have somewhat responded to these critiques. For example, Paul Romer has recently taken the discipline to task in his paper, 'Mathiness in the Theory of Economic Growth'. "Mathiness lets academic politics masquerade as science", he writes. As pretence, "mathiness" allows "slippage between statements in natural versus formal language and between statements with theoretical as opposed to empirical content" $(2015 a, 89)$. There is merit to this point. Indeed, Acemoglu and Robinson provide a case in point when they seize upon Marx's polemic adage "The handmill gives you society with the feudal lord; the steam-mill, society with the industrial capitalist" to claim that Marxian material analysis is a theoretical cul-de-sac. (If academic politics was the standard, then I could reiterate Marx's rhetorical barb that "Economists have a singular method of procedure" and claim that as sufficient proof for definitive argumentative victory.) Still, Romer's solution is to swap academic politics for ideal science, as it can bring "unique clarity and precision in both reasoning and communication". Indeed, he adds that "It would be a serious setback for our discipline if economists lose their commitment to careful mathematical reasoning" (2015b).

While I have a qualified endorsement of this view, I do not think Romer's proposal is grounded in an adequate conceptualisation of the effects of quantification practices, even in their ideal form. As Mary Morgan notes, "adopting a new reasoning style into a science does not come without significant consequences for its content" $(2012,17)$. Indeed, the methodological decisions that econometricians use to devise models that test data to develop economic theories themselves create explications (Morgan 1996, 263-264). For her, this act of creation is not simply one of pure logic but permits ideological encoding to be integrated into the means of inquiry. This is not to diminish the difficulty of econometric model-making, nor to besmirch the skill and craft involved. Rather it is to underscore the social components that also reside in the mode of analysis.

As an example of how the social is encoded in a mode of inquiry, consider Geoffrey Bowker and Susan Leigh Star's observation that while "ordinarily invisible", disputes about orthodox statistical classification measures can become "fraught with political passion" because symbolic and material dividends are consequences of categorisation $(2000,3,4)$. These disputes demonstrate the extent to which statistics have power in public discourse to skew life chances; why else would they be an object of and instrument in struggles? For example, from her study of high financial practices in the early 2000s, the kind of activities that led to the 2008 sub-prime mortgage crisis, Saskia Sassen writes that "assemblages of complex types of knowledge and technologies including algorithmic mathematics, law and accounting, and high-level logistics - have generated complex predatory formations $(2017,1)$. Sassen suggests that complexity hides this predation (becoming ordinary, to use Bowker and Star's terminology), and instead creates barriers for who can pose as economic authorities.

Given the rise of data brokerage as a sizable economic sector, the democratic critique of opacity, access, and diversity in the analysis of data and its role in public life has merit (Pasquale 2015). But it is also incomplete. When complex social issues are 
represented and addressed via quantities, the political becomes technical, thus substituting for and discarding the kinds of democratic discussions Jervens, Merry, Latour, Woolgar, Desrosières, and Sassen draw our attention to. In other words, the quantification of social phenomena changes the conceptualisation of distinction between the realm of the political and the realm of the technical. This makes the quantification of social affairs even more pernicious as it sublimates inherently political practices to render them subject to formal logic.

To develop this theme further, as well as to connect it to more foundational relations in capitalist realism, in the next section I turn to Lukács' ontology, which is central to his critique of reification, a concept that figures prominently in the Frankfurt School analysis of late modernity. Reification, I suggest, is at the foundation of the ideological ontology econometrics serves. Thereafter I turn my attention to Marcuse's critique of one-dimensional society to draw links between the underlying 'laws of motion' between 20th-century bureaucracy and 21st-century econometric analysis.

\section{Reification, Mystification and Alienation}

When Morten Jerven writes that "Freedom House actually does not measure 'democracy'; that the Consumer Price Index does not actually measure 'inflation'; nor does Transparency International actually measure 'corruption.' We just pretend 'as if' they do" (2016), he is appealing to the concept of reification. Within Western Marxism, Georg Lukács is well known for articulating and deploying this concept to sustain a critique of the rational organisation of social life, this itself being enfolded within capitalism's maturation. He rather famously uses the clock as an explanatory metaphor to discuss the rational control of labour. He says, "time sheds its qualitative, variable, flowing nature; it freezes into an exactly delimited, quantifiable continuum filled with quantifiable 'things'” (Lukács 1971, 90). To simplify, he suggests that in capitalist industrialisation social relations becomes objectified and abstracted away, this process facilitated by conceptual systems wherein the ruling class and their agents see labourtime as just another calculable quantity in their ledgers. Here, "quantification is a reified and reifying cloak over the true essence of the objects and can only be regarded as an objective form" $(1971,166)$. Through adopting this stance, the ruling class take on the "attitude of the experimenter" $(1971,131)$, believing that their positions give them control, and that this control is "uninterested" in the social quotients of production (1971, 166). In this permutation, reification illustrates the epistemic error where the products of structural forces cannot be treated as an isolated event, but part of a wider social system.

To my mind, Lukács' description of the quantification of human labour-time being integral to capitalist production is an insight that can be extended to quantification more broadly and econometrics in particular. Econometrics is an exemplary methodological practice of the kind of abstract conceptual system which objectifies and neglects social and political processes through the application of duly deemed neutral and practical observation. To elaborate, as a 'reified and reifying cloak', quantification constructs an object ready for technical manipulation and bureaucratic recognition. And, much like reification, quantification has ideological effects that mediate and constitute relationships between subjects and objects in ways that call back to the process of commodity fetishism. What I mean is that the history of the labour process is eclipsed in the same manner that the commodity becomes the dominant social form. In effect, Lukács is adamant that reification emerges out of the kind of complexity where the distinction between the material and the conceptual is obliterated. 
Picking up on Lukács' analysis, Horkheimer and Adorno repurpose it to form a critique of rationality. This critique is not concerned with the analytical method per se, but rather with a society that "equates thought with mathematics" in the "assumption that the trial is prejudged", condemned to its own measure $(2002,18 ; 20)$. Their principal aim in the Dialectic of Enlightenment is to argue that that unchecked rationality is unreasonable. I understand them to mean that rationality becomes an "automatic process" $(2002,19)$ when subordinated to positivism's tendency towards reification, in which a bifurcation places rationality in opposition to irrationality, this dichotomy grafted onto a conception of distinct modern and pre-modern modes of understanding. However, this presumption is largely incorrect, as the rationalism of modern societies has ritualistic mythical components, one of which is the deference to calculations and qualification. They put it bluntly: "Mathematical procedure became a kind of ritual of thought". These short excerpts illustrate their awareness of how the separation of the subject from the objects of technical practice results in the 'equation of thought with mathematics', a ritualistic process by which subjective human testimony is subordinated to objective concrete numbers. Quantification not only renders the numbers with an objective appearance, but also with procedural neutrality. To call back to econometrics, the remedy is to "grasp existing things as such, not merely to note their abstract spatial-temporal relationships" $(2002,20)$. So where political economists like Acemoglu and Robinson see precision, critical scholars like Horkheimer and Adorno see alienation.

When presented in this fashion, it is easy to see how Lukács' notion of reification has informed Horkheimer and Adorno's analysis of rational modelling, particularly in their shared concern regarding the severance of the subject-object dialectic, as seen in the commodity form and in the mathematization of society. This suggests that they all recognise that capital social relations have generated an epistemology. Put succinctly, "Knowledge in class-based societies is class knowledge", as Christian Fuchs notes; this characterisation "does not mean that the knowledge of the dominant class is always false and the one of the dominated class always true (the opposite can be the case), but rather that knowledge in class-based society is shaped by struggles about how to and who can define reality" (Fuchs 2016, 89). To call back to econometric reasoning, while it has institutional status and credence - and these certainly matter the more fundamental issue is that it is one prevailing means by which mathematization and formal modelling comes to objectify the social world, thereby substituting in class knowledge, assumption and axioms for a more grounded and dialectical comprehension of the social world. It is, in other words, a kind of one-dimensional methodology.

As I begin to conclude this article, I want first to briefly address Marcuse's critique of one-dimensional society to show that econometrics helps to regulate capitalist 'laws of motion', rather than providing opportunities for reflection and critique. Thereafter, I will return to and elaborate upon the topic of econometrics as a neo-positivist method rooted in anti-dialectical thought.

Marcuse's critique begins with social changes in post-war American life wherein procedural-pluralist liberalism and technocratic administration had gained ascension. Whereas scholars like John Rawls and Robert Dahl saw the foreclosure of struggles over first order value, Marcuse noted a contradiction where, despite greater wealth, goods, and services, the workday had also increased and intensified, meaning that workers could not benefit fully from this wealth, or these goods and services. As opposed to procedural-pluralism, post-war American capitalism, Marcuse proposed, had rather redeveloped mechanisms of rule to contain and defuse revolutionary dissent. It took the form of converting any specific deviance into general compliance; dissent be- 
came another means to reproduce the capitalist order. What remained was mild transgressions and defiance, actions alienated from any unconscious revolutionary spirit. The development of 'repressive desublimination' effectively removed sources to challenge the wider dominant social structure: actions associated with these mild transgressions are neither revolutionary nor emancipatory.

Sparing all but essentials, in Eros and Civilization, Marcuse sought to explain repressive desublimination by weaving together Marx's conception of surplus labour which demonstrates that capitalism rests on the exploitation of the working class - and Freud's argument of modernity as inherently repressive elements which sublimate unconscious erotic desires or instant gratification. ${ }^{2}$ This produced the concept of surplus repression. Like surplus labour, surplus repression is over and over what is required for social reproduction; that is, its function is to maintain unyielding capital accumulation by inducing labour deference under demands of high productivity - here workers psychologically internalise and act in accordance with capital's interests, thereby naturalising repression at the expense of acknowledging the unequal property relations between themselves and capitalists. As such, surplus repression does little to aid the worker and everything to aid the capitalist to increase their profits. Invoking Friedrich Schiller, for Marcuse the solution was to rehabilitate art, which would allow "a total revolution in the mode of perception and feeling" (Schiller, quoted in Marcuse 1966, 189). As the task in this article is less an appraisal of his solution, I will leave that kind of extended assessment for another day. Suffice to say that intersubjective harmony is necessary, as is the reconciliation of sense and reason, if the revolutionary path to human fulfilment is to be achieved. One step on that journey requires overcoming the reifications created by capitalist societies.

Having outlined how the quantification within econometric reasoning is a reification that sets a stage for anti-dialectical thought, it is worthwhile viewing a recent incarnation in the long tradition of positivism. Positivism, for Adorno, is a standpoint with "categories as simply given" that are generally subsumed by class relations. This kind of subjectivism, as Habermas demonstrates in his essay 'The Analytical Theory of Science and Dialectics', is but one standpoint seeking to exclude whole areas of human knowledge that cannot be known through formal methodological rules $(1977,137)$. In accounting for the development of this complex social phenomenon that posits a rational 'objective' mode of understanding, Marcuse writes that "Positivism shifts the source of certainty from the subject of thought to the subject of perception. Scientific observation yields certainty here" $(1955,351)$. All told, positivism is founded on a specific conceptual set of ontological and epistemological stances which presumes that subjects can stand adjacent to ontology and epistemology and that conceptual elements are neutral rather than neutralising their constitutive objects. This would certainly be a fair assessment of the kind of political economy practiced by Acemoglu and Robinson.

To the extent that one can do justice to the topic in an essay, it is worth contrasting positivism with Adorno's conception of dialectics, drawing primarily from Negative Dialectics. Set in opposition to German idealism, whether Kantian or Hegelian, Adorno's materialism proposes that efforts to separate the subject and object are deeply misguided: even more so when seeking to give priority of the subject. This is because the

${ }^{2}$ Marcuse's analysis rejects the Freudian conception of the necessity of the Reality Principle's trumping the Pleasure Principle, indeed favouring the normative conception of de-alienated labour sketched by Marx. More generally, for Frankfurt School theorists, the universality of Freud's pessimism is a conservative foreclosure to the very possibility of revolutionary action; neither is it attuned to 'the whole man'. 
subject is itself an object constituted by society more broadly, that it could not exist without society. The task that Adorno sets himself, then, is to break the prevailing deceptive fallacy of "constitutive subjectivity" and instead promote "reconcilement" (2004, $x x ; 6)$. One part of this larger task involves reopening issues of metaphysics in philosophy; its counterpart is to undertake an offensive against positivism.

This returns us to the important differences between Lukács' and Adorno's respective stances on the conceptualisation of knowledge more broadly. As Susan BuckMorss notes, for Lukács, alienation was a result of reification stemming from bourgeois society, that bourgeois society was set on destroying culture by making artists unable to create a unity between subject and object. Accordingly, Lukács put considerable stock in the proletariat to create this unity as history unfolded and this class became the agent for restoring a lost totality. Adorno vehemently disagreed. His conception was that knowledge of history was also historical. This give rise to his adage, "History is in the truth; the truth is not in history" (Adorno, quoted in Buck-Morss 1977, 46). Indeed, as he indicates, "dialectics [is] not a standpoint." (Adorno 2004, 4).

\section{Conclusion}

At the risk of broad generalisation, in the 18th and 19th centuries, political economy was predominantly a verbal science, its subsequent Marxian critique very much marginalised from the academy. By the late 20th and early 21 st century it became mathematized with bounded formal modelling of financial transactions, decisions within firms, and national economies becoming standard practice. Granted, there are many varieties of political economy being practiced today, ranging from constitutionalism, social choice and public economics, to macroeconomics, historical developmental, and international political economy (see Weingast and Wittman 2006); nevertheless, complex statistical modelling is central to effective governance, a vital component of technical administration and control. This holds even in democratic governance. This development has given rise to a technocratic elite with its own languages of expression and ways of reasoning that form an epistemic genre. This connection is made via the application of calculability, using mathematics to present what appears to be a formal logic. Yet the excision of Marxian critiques has been very much to the detriment of making political economy a critical social science.

Econometrics is but one of the more recent examples in the history of quantification practices. Herein social affairs are treated as objects ripe for impartial - and thus authoritative - technical manipulation, thereby mystifying the social realm. The shorthand expression of this is to say that econometrics is a positivist rendering of the social structure, seeking to rearrange the material world in its own image by pursuing a mathematical characterisation of social life. It is, as I have suggested, a depoliticisation of the social question rendered through the dominance of anti-dialectical thought. This weakness is papered over by mathematical sophistication, institutional clout, and ideology, all on display in the reception of Acemoglu and Robinson's analysis and method.

To be clear, this is not to say that these numbers cannot at times be useful or have practical utility. As the progress towards the Millennium Development Goals illustrates, technical operations using quantities can help to promote human flourishing. Rather it is to say that numbers can function as a form of class knowledge, which in turn shapes reality. In late capitalism the reasonable bounds of quantification have been unreasonably extended to all areas of human life, seeking to capture and reduce senses and experiences. Quantification, with its aura of objectivity and neutrality, is just the most recent incarnation of an influential intellectual lineage within modernity seeking to construct and administer objects in a technical manner. Motivating this extension is the 
spectre of positivism, so naturalised that it is almost unperceivable, but still very much present.

In this article I have argued that the anti-dialectical standpoint provides goods suspect of ritualistic quantification and mathematical modelling in econometrics. Being a mode of analysis severed from questions about the origin of its production, the reason for its circulation, and its class character, it is important to pay attention to the kinds of objects that econometrics produces, as there are sociological consequences of a social world structured by this symbolical mediatisation. For while econometrics appears to demonstrate the apparent object authority of data, the skilful manipulation of the latter demonstrates expertise that allows one to control the administration of political subjects. This technical operation does not fully permit a discussion about human values through a framework where there is little prospect of reconcilement. I am hopeful that this will change, but change has to tackle the fetish in the wider computational turn currently under way in the social sciences, a turn where modelling and quantification comes at the expense of studying the history of social processes. The primary task ahead, as I see it, is to find the opportunity and means to insert dialectical thought into the wider discussion about data analysis for social justice, or to assess if this task is even possible.

\section{References}

Acemoglu, Daron and James Robinson. 2019. The Narrow Corridor: States, Societies, and the Fate of Liberty. New York: Penguin Press.

Acemoglu, Daron and James Robinson. 2012a. Why Nations Fail: The Origins of Power, Prosperity and Poverty. New York: Crown Business.

Acemoglu, Daron and James Robinson. 2012b. How Marx Got it Wrong [blog post]. Accessed 27 March, 2020. http://whynationsfail.com/blog/2012/5/11/how-marx-got-itwrong.html

Acemoglu, Daron and James Robinson. 2006. Economic Origins of Dictatorship and Democracy [e-book]. Cambridge: Cambridge University Press.

Adorno, Theodor. 2004. Negative Dialectics. Translated by E. B. Ashton. London: Routledge.

Adorno, Theodor. 1977. Introduction. In The Positivist Dispute in German Sociology, by Theodor W. Adorno, Hans Albert, Ralf Dahrendorf, Jürgen Habermas, Harald Pilot and Karl R. Popper, 1-67. Translated by Glyn Adey and David Frisby. London: Heinemann.

Anderson, Perry. 1974. Lineages of the Absolutist State. London: Verso.

Bowker, Geoffrey and Susan Leigh Star. 2000. Sorting Things Out: Classification and Its Consequences. Cambridge, MA: MIT Press.

Breckenridge, Keith. 2014. Biometric State: The Global Politics of Identification and Surveillance in South Africa, 1850 to the Present. Cambridge: Cambridge University Press.

Buck-Morss, Susan. 1977. The Origin of Negative Dialectics. London: The Free Press.

Collins, Chuck and Josh Hoxie. 2017. Billionaire Bonanza: The Forbes 400 and the Rest of Us. Report for the Institute for Policy Studies, November 2017. Accessed 27 March, 2020. https://ips-dc.org/wp-content/uploads/2017/11/BILLIONAIRE-BONANZA-2017-FinalV.pdf

Davies, William. 2017. How statistics lost their power - and why we should fear what comes next. The Guardian, 19 January. Accessed 27 March, 2020. https://www.theguardian.com/politics/2017/jan/19/crisis-of-statistics-big-data-democracy

Desrosières, Alain. 1998. The Politics of Large Numbers. Translated by Camille Naish. Cambridge, MA: Harvard University Press.

Drazen, Allan. 2007. Review I, in Four Reviews of Economic Origins of Dictatorship and Democracy. The Economic Journal 117 (517) (February): 162-183.

Easterly, William. 2007. Review II in Four Reviews of Economic Origins of Dictatorship and Democracy. The Economic Journal 117 (517) (February): 162-183. 
Fuchs, Christian. 2016. Critical Theory of Communication. London: University of Westminster Press.

Habermas, Jurgen. 1977. The Analytical Theory of Science and Dialectics. In The Positivist Dispute in German Sociology, by Theodor W. Adorno, Hans Albert, Ralf Dahrendorf, Jürgen Habermas, Harald Pilot and Karl R. Popper, 131-162. Translated by Glyn Adey and David Frisby. London: Heinemann.

Horkheimer, Max and Theodor Adorno. 2002. Dialectic of Enlightenment. Stanford: Stanford University Press.

Jerven, Morten. 2016. Review of Cooley, Alexander; Snyder, Jack, eds., Ranking the World: Grading States as a Tool of Global Governance. H-Diplo, H-Net Reviews [website]. http://www.h-net.org/reviews/showrev.php?id=45200

Jerven, Morten. 2015. Africa: Why Economists Get It Wrong. London: Zed Books.

Jerven, Morten. 2013. Poor Numbers: How We Are Misled by African Development Statistics and What to Do About It. Ithaca: Cornell University Press.

Latour, Bruno and Steve Woolgar. 1986. Laboratory Life: The Construction of Scientific Facts. Princeton: Princeton University Press.

Lawrence, Peter. 2010. Development by Numbers. New Left Review 62, March-April: n.p. Lukács, Georg. 1971. History and Class Consciousness. Cambridge, MA: The MIT Press. Mann, Geoff. 2017. In The Long Run We Are All Dead. London: Verso.

Marcuse, Herbert. 2002. One Dimensional Man. Routledge: New York.

Marcuse, Herbert. 1966. Eros and Civilization. Beacon Press: Boston.

Marcuse, Herbert. 1955. Reason and Revolution. Routledge \& Kegan Paul Ltd: London.

Merry, Sally Engle. 2016. The Seductions of Quantification: Measuring Human Rights, Violence against Women, and Human Trafficking. Chicago: University of Chicago Press.

Morgan, Mary. 2012. The World in the Model. Cambridge: Cambridge University Press. 2012.

Morgan, Mary. 1996. The History of Econometric Ideas. Cambridge: Cambridge University Press.

Pasquale, Frank. 2015. The Black Box Society. Cambridge, MA: Harvard University Press.

Piketty, Thomas. 2017. Why Save the Bankers? Translated by Seth Ackerman. Boston: Mariner Books.

Rodney, Walter. 1981. How Europe Underdeveloped Africa. Washington: Howard University Press.

Romer, Paul. 2015a. Mathiness in the Theory of Economic Growth. American Economic Review: Papers \& Proceedings 105 (5): 89-93.

Romer, Paul. 2015b. My Paper "Mathiness in the Theory of Economic Growth". https://paulromer.net/mathiness/

Saez, Emmanuel and Gabriel Zucman. 2014. Wealth Inequality in The United States Since 1913: Evidence From Capitalized Income Tax Data. NBER Working Paper 20625.

Sassen, Saskia. 2017. Predatory Formations Dressed in Wall Street Suits and Algorithmic Math. Science, Technology \& Society 22 (1): 1-15.

Scott, James, C. 1998. Seeing Like a State. New Haven: Yale University Press.

Thompson, John. 1995. Media and Modernity. Cambridge: Polity Press.

Tilley, Helen. 2011. Africa as a Living Laboratory: Empire, Development, and the Problem of Scientific Knowledge, 1870-1950. Chicago: University of Chicago Press.

Timcke, Scott. 2017. Capital State Empire. London: University of Westminster Press.

Tooze, Adam. 2001. Statistics and the German State, 1900-1945: The Making of Modern Economic Knowledge. Cambridge: Cambridge University Press.

Weingast, Barry and Donald Wittman. 2006. The Oxford Handbook of Political Economy. Oxford: Oxford University Press.

Wolff, Edward. 2017. A Century of Wealth in America. Cambridge, MA: Harvard University Press. 
Wolff, Edward. 2014. Household Wealth Trends in the United States, 1962-2013: What Happened over the Great Recession? NBER Working Paper No. 20733.

\section{About the Author}

\section{Scott Timcke}

Scott Timcke is a comparative historical sociologist interested in the study of race, class, and inequality. His approach to these topics is greatly shaped by South African and Caribbean critiques of the Anglo-American liberal tradition. 